\title{
Regional Impacts of Environmental and Global Change: Water Use in the Valais
}

\author{
Ellen Wiegandt, Geneva and Sion
}

\section{Crucial questions about global change and globalization}

Concern with the state of the environment is not a new phenomenon. Indeed, the history of humanity is the story of historically specific adaptation to different physical settings with the help of technologies and institutional frameworks. It has always been necessary for people to seek an equilibrium between supply of resources from the natural environment and demand created by human needs and wants. In this context, water is exemplary because it not only is essential for the maintenance of human life, it indirectly ensures mankind's survival by supporting plant and animal life. Over time, water has also come to play a central role in technological development as a source of energy. Multiple uses of water mean that there are simultaneous environmental, economic and social aspects to consider. Devising strategies to meet all these needs is the challenge of sustainable development. An analysis of water use provides a means to highlight key dilemmas of global change, globalization and sustainable development.

These issues confront society at all levels. At the international level, agencies and programs dealing with resource use and sustainable development have defined certain critical regions and resources as a focus for particular attention because of the unique convergences of physical and social aspects. Mountains have been identified as one of these critical regions because of the role they play as water towers, as repositories of biodiversity and as zones of cultural and institutional richness. In Switzerland, the international importance accorded to mountain regions is enhanced by their central place in the national physical, economic, and social environment. More generally, the convergence of water and mountains raises a long-standing problem of sustainable development, which takes on added importance in the current debate on global climate change.

Historically, communities were largely dependent on resources available locally and had to meet the needs of each generation without compromising the welfare of generations to come. The core of the Swiss institutional framework created to meet this challenge grew out of age-old efforts to regulate interactions with the natural and social environments. In the past, some of the most intractable problems concerned regulation of scarce resources. The solution put forward by the early Alpine confederates was to create economic communities that exercised strong local control over resources such as land, water, and forests. The essential structures remain today but have been strongly overlaid by cantonal and federal legislation shifting responsibility and power to higher levels of organization. In response to concerns about climate change, emerging international environmental regimes will add yet another level to the regulation of resource use by imposing international standards and creating pressures for harmonization among different national legislative traditions.

In addition to the socio-economic processes affecting water use, the quantity, quality, and seasonal availability of water is expected to be influenced by global change. Recent research examines the consequences of projected temperature increase on the water cycle (The brief description of the water cycle that follows summarized of the conclusions of numerous research projects undertaken in the context of the Swiss National Research Program 31: Climate Change and Natural Disasters; cf. BADER \& KUNZ 1998). Important uncertainties remain in the prediction of regional effects but tendencies identified for Alpine regions suggest changes in the annual distribution of precipitation with an increase in winter and a decrease in summer. In Switzerland as a whole, this will result in an annual decrease in water flow. In Alpine areas, the additional factor of snow cover and summer snow melt must be taken into account to evaluate annual and seasonal water availability. Regions at lower altitudes will have less snow in winter because of higher temperatures and less water in summer because of lower rainfall and increased evaporation rates. At higher elevations, winter precipitation will bring greater snowfalls and this accumulated water will be released during spring and summer melting. With the onset of melting occurring earlier because of higher temperatures, the total permanent snow cover will diminish as well. At the same time, the water flow will be more regular and the present peak flow in June will decrease in favor of a more uniform pattern. In summary, current research results point to changes in the rhythm of water availability with a potential tendency for a decrease in water resources. Great uncertainties remain, however, and these will add to to complexities arising from new market changements. As a result, numerous factors must be taken into account when designing effective water management strategies for the future.

In this context, control over water use for hydroelectric power generation in the Valais provides a good example of the implications of environmental and institutional change for resource use and management at the regional level. It brings together climate issues, the history of institutions, and the challenges of Switzerland's adjustment to a more international world of multilateral nego- 
tiations and open markets. In looking toward the future of water use in the Valais, it is nevertheless useful to reflect on the historical patterns and to study the dynamic process of the opening of closed regions and the pressures for change that derived from this evolution.

In analyzing the convergence between institutional aspects of resource use and the impact of global change and globalization on future arrangements in the Valais, we will address three inter-connected aspects:

- The concept of sustainable development.

- The use of water in a peasant society in the Valais of the past century. The analysis identifies a set of institutions that organized the use of crucial resources, particularly water. We will show how society in the past attempted to achieve a balance between the supply and demand of water.

- The future challenges posed by climate change, globalization and market liberalization. We explore, for example, the effects of these parallel processes on the supply of and demand for water and their impact on political, economic, and social institutions. We ask to what extent local institutions, forged by the history of an essentially rural and autonomous society, can adapt to pressures for openness in the context of a changing environment.

\section{Sustainable development}

Concern about future water use in the Valais is a regional issue, nevertheless tightly linked to the global problems of resource use through time. Increasingly we ask whether the resources we exploit today will be available in the necessary quantity and with the necessary quality to assure needs of future generations. This is the very essence of sustainable development as defined by the report by the BRUNTLAND COMMISSION (1987) and has stimulated a wide debate about resource use, sustainability, and equity.

Zero consumption of resources does not constitute sustainable use because no living species could survive without food and water (SoLow 1991). Thus some level of resource use is necessary to sustain current population. The challenge is to determine the level of consumption that can take place which will be sufficient to meet the needs of the present without compromising the well-being of future generations. This question is particularly acute for non-renewable resources but must be asked for renewable resources as well because too-intensive use may alter their quality and, ultimately, even their quantity. We must, therefore, elaborate mechanisms to determine our rights and obligations toward resources and towards current and future populations. We are thus led to examine fundamental questions of property rights, which have both spatial and temporal as well as individual and collective aspects.

\subsection{Space and time}

Property rights over resources define the terms of use of these resources but, in the case of private property, do not necessarily set the rate of exploitation. For example, an owner of an oil well can decide on the rate of extraction. $\mathrm{He}$ is usually influenced by an evaluation of the future, particularly of the estimate of the projected price, which is reflected by interest rates and internalized in current prices. High interest rates therefore encourage owners to maximize profits by rapid resource extraction, thereby affecting future supply. Low interest rates, on the other hand, lead owners to conserve their resources in the hopes that the future will bring greater chances of profit. In the latter case, however, they may take advantage of low interest rates to invest in infrastructure development (dams or roads, for example). This too has an impact on the environment. Thus two different time preferences - for present or for future can have a negative effect on the environment. This example embodies the so-called conservationist's dilemma: all solutions may have negative consequences for the environment over the long-term (These observations reflect the important work of Harold Hotelling 1931).

Fiscal and monetary policies shape and reflect society's relation to time by determining the rate of extraction of resources but give no clear signal about the effects on the environment. These policies also influence spatial distribution of environmental effects by encouraging the use of given resources through subsidies, taxes etc. with particular impacts on the regions where resources are concentrated. Differences will likely emerge between states favoring present consumption and those favoring conservation of resources. There is thus an implicit choice between equitable distribution of resources over time or over space. Deferring present consumption to assure future resource availability may imply renouncing economic development that could potentially bring better health and social conditions for current populations. Such trade-offs must be carefully weighed if they imply that present conditions deteriorate and the potential for social conflicts increases. Conflict today could also jeopardize future well-being. Such dilemmas are often faced by developing countries caught between achieving sustainable development and meeting international environmental standards.

\subsection{Individual and collective norms}

These considerations refer both to mechanisms functioning within and impacts of decisions made by groups of individuals (either people or firms) who have rights to resources and are free to dispose of them as they please. On the other hand, there are resources which historically have been treated as public goods and have been managed under common property regimes or have largely escaped all property rules, such as air or oceans. Given emerging international environmental regimes which 
often assume common property rules, it is important to look more closely at how previous common property systems functioned in order to evaluate whether they lead to different kinds of resource use or whether they have particular advantages or disadvantages for resource management or equity issues. A study of water is particularly appropriate in this context because it has often been managed as a public good at local, national, and international levels.

The environmental effects of common property resources have been the subject of intense debate since the 1960 's when an article on the "tragedy of the commons» argued that resources shared by several users were rapidly depleted because each owner sought to maximize his individual gains while shifting the responsibility and costs of maintaining the resource to the other users (HARDIN 1968). Accordingly, common property regimes are in total opposition to goals of sustainable development because they offer no incentive for users to maintain resources for future use. On the contrary, each user/owner seeks to gain immediate and individual advantage.

The history of Valais resource management seems to contradict this interpretation. Indeed, over several centuries, the production system incorporated both private and common property regimes. A brief historical overview describes how one resource, water, was used and how its management in the past laid the institutional foundation for current and future application to sustainable development principles and market liberalization.

\section{Historical patterns of water resource use and management}

Locally and globally, water issues are of singular importance in mountain regions. It is here that most great rivers have their sources. Control over flow and distribution confers a strategic role to mountain areas in which water and politics are inextricably interconnected. Particularly in arid and semi-arid regions where scarcity jeopardizes well-being, water issues dominate regional politics (cf. the Middle East). In the Valais, water resources are more abundant but regulation of seasonal variation and distribution in space nevertheless played an important role in the past. As water was, and still is, essential for human and animal consumption and also, in many regions, for irrigation, complex systems of property rights and management strategies were developed to assure access throughout the year and over the long-term. Water also became an important source of energy for early industry and evolved into a significant source of income with the construction of hydroelectric dams during the 20th century.

In order to balance multiple uses of water with the supply available from the natural hydrological cycle, mountain populations developed social strategies af- fecting all sectors of society. Cultural norms and community regulations influenced population (the demand side for resources) and production system (the supply side, transforming natural resources into goods for consumption) and addressed equity issues through rules about the distribution of resources. The resulting social system in the Valais was a combination of private and common property regimes. Fields, most pastures and buildings were owned individually. Water, forest and alpine pastures were community property resources, as is frequently the case where the nature of the resource poses allocation or maintenance problems. These resources were managed by user associations which imposed strict rules of use. This prevented individual capture of a crucial resource and assured an efficient and equitable distribution network, thus avoiding a «tragedy of the commons» situation of overuse and depletion (NeTting 1981, WiegandT 1980).

Just as institutions and processes shape the supply of resources, they affect the demand situation. For example, demographic mechanisms and cultural rules influence population growth. Thus, over time, population size was influenced by the tendency towards late marriages, high celibacy rates and high emigration rates (Ibid.).

Communities also controlled access to collective resources by modifying conditions granting or restricting bourgeoisie rights to outsiders at moments when resources were abundant or scance (WIEGANDT 1977). Distribution of resources was controlled long-term by the inheritance system; short-term adaptation to demand was possible because of widespread use of storage for individual or collective use.

Historical analysis thus suggests that the integrated system of resource use and management adopted in the Valais prevented overexploitation and dissipation of a scarce resource base and thus avoided a «tragedy of the commons». This is not necessarily the case in all regions. It seems that, on the contrary, when property rights are not clearly defined or when the institutional framework is insufficient for rule enforcement, overuse can lead to overexploitation and environmental degradation. Subsistence production is in fact particularly vulnerable to such scenarios because workers who have to meet their own minimal needs will produce even at times of declining returns. Real costs of production are not taken into account in the price, which leads to everincreasing intensification and, ultimately, to resource depletion. This process characterizes many developing countries whose systems operate in world markets in which other regions have well-defined property rules and cost internalization (See CHICHILNISKY 1994 for a detailed development of this argument.).

While these distortions do not characterize the past in the Valais, it is useful to ask to what extent the institutional framework, inherited from the period of closed communities and subsistence agriculture, is able to 
adapt to new conditions such as those being created by emerging international and economic regimes. Opening the electricity market and conforming to international standards of greenhouse gas emissions will lead to new definitions of water use in Switzerland and will directly affect a crucial sector of the Valaisan economy. Is the system sustainable; is it capable of adapting to new conditions?

\section{Future water use in the context of global change and market liberalization}

The closed system, in which community resources were used essentially for community survival, began to open at the beginning of the 20th century with the introduction of industries using hydroelectricity. An important consequence of this process of industrialization was the creation of new sources of revenue for both individuals and for communities. In 1989, a study attempted to measure the effect of hydroelectric infrastructures on the Valaisan economy and concluded that it contributed over CHF 34 million, representing an average of CHF 22000 per active worker p.a.. Indirect effects amounted to $36 \%$ of the cantonal revenue (MATTEI 1989: 20, 27). Moreover, concessions sold to exploit the water brought direct revenues to communes and the canton, representing $16.3 \%$ of cantonal tax revenues and an average of $9.5 \%$ for communal taxes (with peaks of as much as $20 \%$ in some communes) (BHP 1997: 79). Clearly, water is strongly linked to many aspects of life in the Valais: Its basic role in domestic consumption remains essential. Its importance for agriculture remains unchanged even though the agricultural sector now plays a smaller role in the regional economy. In addition, water has acquired new uses as a source of energy and as a fundamental component of the tourist industry to supply direct needs of tourists or to make snow for skiing. In the coming years, we can expect an increase in competition among different users with this process strongly affected by the quantity and quality of water available. Human actions such as dam construction, modification of river beds and industrial development will alter the water supply. Natural processes such as global climate change will have equally significant impacts, as was described earlier. Water demand is continuously changing and may increase in the Valais as a result of economic development, tourism, and demographic evolution. The strong relation between supply and demand amplifies the problem because changes leading to greater use can result in further changes in quantity and quality.

At the heart of the debate over water use is the future of hydroelectricity in Switzerland and the impact of changes in its current role on the Valais. The debate brings together problems of climate change and globalization. The processes involved run both parallel to each other and intersect each other at the international and national levels, and have led Switzerland to proposing new energy laws that meet economic goals of liberalization, environmental goals of greenhouse gas reduction and sustainable development, and fiscal goals of social equity. The laws will impinge strongly on the institutional framework traditionally regulating water use in the Valais and thus imply significant consequences for existing power relations within Switzerland.

\subsection{Electricity and the new legal framework in Switzerland}

A new law regulating the electricity market is currently under discussion in Switzerland. It has its origins in the deregulation processes propagated by the European Union since 1996. Although not a member of the EU, Switzerland is strongly influenced by major EU policies. Switzerland is also an integral part of the European power grid because of its capacity to store water and to supply electricity on demand internationally. This ability to cover peak demand is set however in a market characterized by overcapacity. The proposed law aims to redefine Swiss energy production within the current economic and political landscape. At the same time, environmental issues may also be addressed. Increased competition resulting from market liberalization is expected to increase efficiency; incentives to use renewable energy sources such as water are aimed at promoting sustainability. The mechanism under discussion is a tax on non-renewable energy sources. The revenues generated would be used to keep prices of hydroelectric power competitive.

The new market situation and proposed policies to regulate it are directly linked to the global change debate. International environmental negotiations impose particular constraints and pressures on Switzerland, even in areas which were previously the exclusive domain of domestic legislation and institutions. In negotiations following the Kyoto Protocol, for example, Switzerland agreed to reduce its greenhouse gas emissions to $8 \%$ below 1990 levels. Several regulatory frameworks exist to help achieve this goal. At the international level, command and control regulations are common. For example, rules for production, use, trade and supervision were adopted in the Montreal Protocol to preserve the ozone layer. Among the accepted regulatory strategies approved within the Kyoto Protocol is the right to produce certain levels of greenhouse gases and the possibility to trade unused quantities using emission permits. This in effect defines a new form of property rights over emissions. Another regulatory instrument, corrective taxation, was first suggested in 1920 by the British economist PIGOU. Although not present at the international level, it is a very common regulatory mechanism at the national level, and it is the mechanism chosen by the designers of the Swiss electricity law. Given the complex situation of different regulatory strategies hav- 
ing to fulfill the goals of legislation, and the simultaneous local, national and international character of resource issues, several questions arise. First, will legislation meet the desired environmental goals; second, are environmental and market liberalization policies compatible; and third, will the implicit institutional shifts of power mean fundamental changes in Swiss domestic power relations and in Switzerland's international position?

Taxing non-renewable sources of energy and transferring revenues to subsidize the production of «clean» energy sources is assumed to contribute towards meeting environmental goals. However, taxes act on costs and, therefore, on prices. What are the guarantees that a higher price for energy produced by non-renewable sources will be sufficient to lower its consumption to environmentally acceptable and internationally agreed levels? Moreover, is the distinction between types of electricity according to the form of energy used to produce it compatible with WTO rules requiring like treatment for like products. If non-renewable sources originate mostly outside Switzerland and the renewable sources are domestic (French nuclear vs. Swiss hydroelectricity, for example), legal questions may arise.

The new proposed legislation has important consequences for the existing Swiss legislative framework and the ensuing fiscal autonomy of cantons and communes. Longstanding structures give significant property rights to communes and cantons. In the case of water, it was first regulated almost entirely locally. The federal law of 1916 on the Use of Hydroelectric Force ruled that cantonal legislation would determine which community (canton, district, commune, or corporation) had the right to dispose of the force (?) of the public waterways (art. 2). Already in the beginning of the century, new uses reorganized the property rights arrangements of resources. This has had important financial consequences because the 1916 law also stipulated that communities disposing of the rights to water power could either use them or transfer use-right to others. This ruling is at the origin of the concessions negotiated with electricity companies, which have fundamentally changed the financial structure of numerous communities. It must be noted, however, that improvement of many local economies has been at the price of local autonomy in the sense that the federal law voted by the Federal Parliament sets upper limits to amount of the user fees. The new proposed law also would shift the power to tax to the federal level and direct revenues coming from a well-established property right would be replaced by subsidies derived from the new taxes. Placed in the broader international context of emerging environmental regimes and in the context of Swiss history of local autonomy, this approach is puzzling. While the international community is adopting property rights solutions to solve environmental and energy solu- tions, Switzerland seems to be abandoning them despite its very long history with using precisely these mechanisms to deal with environmental and resource issues.

\section{Thoughts for the future: implications of global change and globalization}

An integrated approach uncovers contradictions among different social goals. As can be seen in the above, it is problematic to implement simultaneously policies leading to environmental protection and market liberalization. Seen as part of the wider process of global change and viewed from a long time perspective with local and global implications, the complexity of achieving sustainable development with all its environmental, social, and ethical dimensions, becomes evident. The purpose of this essay has been to demonstrate the difficulties inherent in meeting current and future needs without endangering the natural environment. It focuses on water because water has always been a fundamental resource and its use has evolved apace with social and economic development. The historical perspective traces ancient patterns of resource management and, in the case of Alpine Switzerland, highlights profound social and institutional changes that may result from the adoption of new regulatory instruments.

For several centuries, the Valais achieved sustainability by assuring the survival of its current population while preserving access to resources for future generations through a combination of measures affecting its production system, demographic regime, and property rights. Local autonomy and decision-making were integral to the success of these arrangements.

Today, the global environment is changing primarily as a result of human activity and the economic and political landscape at the international and domestic levels are also evolving. Reflection on the best strategies for preserving regional identities in a globalizing world is more than ever of necessity. In the case of the Valais, climate change may modify water supply; the opening of the electricity market may disrupt age-old institutional arrangements and generate uncertainties about the consequences of new structures. Historic patterns provided great flexibility, a fundamental quality for adaptation to new needs, to constraints and to the unknowns that face all societies. To be successful, local and global strategies must preserve this flexibility and permit rapid response to new conditions.

\section{Literature Cited}

BADER, S. \& P. Kunz (1998): Climat et risques naturels: La Suisse en mouvement. $-=$ Rapport scientifique final PNR 31. Genève et Zürich: Georg and VDF: 1-312. 
BRUgGer, HANSER UND PARTNER, AG (1997): Öffnung des Elektrizitätsmarktes Schweiz: Folgerungen für die Elektrizitätspolitk der Gebirgskantone. $-=$ Bericht im Auftrag der Regierungskonferenz der Gebirgskantone, Zürich: 1-100.

CHichilnisky, G. (1994): North-South Trade and the Global Environment. - In: The American Economic Review 84,2: 851-874.

HaRdin, G. (1968): The Tragedy of the Commons. - In: Science 162: 1243-1248.

Hotelling, H. (1931): The Economics of Exhaustible Resources . - In: Journal of Political Economy 39: 137175.

Mattei, A. (1989): Estimation du rendement moyen de l'enérgie électrique utilisée dans l'économie valaisanne. $-=$ Cahiers de recherches économiques, Département d'économétrie et d'économie politique, Université de Lausanne n. 8902: 1-31.

NetTing, R. McC. (1981): Balancing on an Alp: Ecological Change and Continuity in a Swiss Mountain Community. - Cambridge: Cambridge University Press.

Pigou, A.C. (1920): The Economics of Welfare. - London: MacMillan.

Solow, R. (1991): Sustainability: An Economist's Perspective, The 18th J. Seward Johnson Lecture. - = Woods Hole, MA, Marine Policy Center, Woods Hole Oceanographic Institution: 1-12.

WIEgand, E. (1977): Inheritance and Demography in the Swiss Alps. - In: Ethnohistory, 24, 2: 133-148.

WORLD COMMISSION ON ENVIRONMENT AND DEVELOPmENT, BRuntLand Commission (1987): Our Common Future. - New York: Oxford University Press.

\section{Summary: Regional Impacts of Environmental and Global Change: Water Use in the Valais}

This paper provides a brief overview of water resources in the Alps from an economic, social and historical point of view. Based on these considerations, the paper looks into the future use of water under conditions of changing climate and a liberalization of economic markets. A particular focus here is the liberalization of the electricity sector in Switzerland. The examples given here provide material to reflect upon the potential conflicting and convergent issues linking globalization and global change.

\section{Zusammenfassung:}

Regionale Auswirkungen des Klimas und der globalen Änderung: Wasserverbrauch im Wallis Dieser Beitrag liefert einen kurzen Überblick über die Wasserversorgung in den Alpen von einem ökonomischen, sozialen und historischen Gesichtspunkt. Basierend auf diesen Erwägungen, betrachtet dieser Artikel den zukünftigen Gebrauch des Wassers unter Bedingungen von Klimaänderungen und der Liberalisierung der Märkte. Ein bestimmter Fokus hier ist die Liberalisierung des Elektrizitätssektors in der Schweiz. Die gegebenen Beispiele versuchen, konflikhafte und konvergente Aspekte von Globalisierung und «Global Change» darzustellen.

\section{Résumé : Impacts régionaux}

de l'environnement et du changement global : Utilisation des ressources en eau en Valais

Cet article fournit une brève vue d'ensemble des ressources en eau dans les Alpes d'un point de vue économique, social et historique. Basé sur ces considérations, le papier examine la future utilisation de l'eau sous conditions de changements climatiques ainsi que sous conditions d'une libéralisation des marchés économiques. Une attention particulière est dédiée à la libéralisation du secteur de l'électricité en Suisse. Les exemples donnés ici fournissent matière à réflexion sur le potentiel de conflit et de convergences dans les problématiques de la globalization et du changement global.

Dr. Ellen Wiegandt, International Environmental Studies Unit, Graduate Institute of International Studies (HEI), University of Geneva, 11 A av. de la Paix, CH1202 Genève; Institut Universitaire Kurt Bösch, 55, chemin de l'Institut, CH-1950 Sion.

e-mail: wiegandt@hei.unige.ch 